\title{
The Correlation of Cyp2e1 Genetic Polymorphism on Alcohol Drinking Habits in Papuan Ethnicity
}

Hubungan Polimorfisme Genetik Cypze1 terhadap Kebiasaan Minum Alkohol pada Etnis Papua

\author{
Mardhatillah Marsa ${ }^{1 *}$, Yudha Nurhantari ${ }^{2}$, Suhartini ${ }^{2}$, Tri Ratnaningsih ${ }^{2}$ \\ ${ }^{1}$ Department of Forensic, Faculty of Medicine and Health Sciences, Universitas Muhammadiyah Yogyakarta \\ 2 Department of Clinical Medicine, Faculty of Medicine, Universitas Gadjah Mada
}

DATA OF ARTICLE:

Received: 24 April 2021

Reviewed: 11 June 2021

Revised: 15 July 2021

Accepted: 29 July 2021

*CORRESPONDENCE:

mardha.marsa@umy.ac.id

DOI:

10.18196/mmjkk.v21i2.11579

TYPE OF ARTICLE:

Research

\begin{abstract}
Alcohol abuse is associated with genetic factors and is influenced by certain races and ethnicities. CYP2E1, which works on the endoplasmic reticulum, produces an enzyme that plays a significant role in alcohol metabolism. In relation to it, this study aims to identify the polymorphisms of CYP2E1*5B and CYP2E1*6 genes in alcohol drinkers of Papuan Ethnics. A total of 39 Papuans were analyzed for alcohol drinking habits. Alcohol drinkers were found to be 29 people (74.4\%), and 10 people $(25.6 \%)$ were non-drinkers. The drinkers mainly were late teenagers $(89,7 \%)$ and males $(69,2 \%)$. The CYP2E1*5B genotypes were $\mathrm{c} 1 / \mathrm{c} 1$ as $94.9 \%$ and $\mathrm{c} 1 / \mathrm{c} 2$ as $5.1 \%$. Meanwhile, the CYP2E1*6 T/T genotypes were $56.4 \%$, and T/A genotypes were $43.6 \%$. The odd ratio for CYP2E1 ${ }^{*} 5 \mathrm{~B}$ were 18,5 and 7,7 for CYP2E1*6. $p>0,05$ for CYP2E1*5B and CYP2E1*6 gene polymorphisms for alcohol drinking behavior in the form of frequency, duration, type, and volume of alcohol consumed. Furthermore, $\mathrm{c} 1 / \mathrm{c} 1$ and $\mathrm{c} 1 / \mathrm{c} 2$ genotype polymorphisms were in CYP2E1*5B; T/T and T/A genotypes were in CYP2E1*6 of Papuan ethnic at Yogyakarta. In conclusion, genotype $\mathrm{c} 1 / \mathrm{c} 1$ had 18,5 times of the possibility of being alcoholic drinkers, and genotype $\mathrm{T} / \mathrm{T}$ had 7,7 times of the possibility of being alcoholic drinkers in Papuan ethnic. It indicated that the type of genotype statistically did not significantly affect alcohol drinking behavior on the subject.
\end{abstract}

Keywords: alcoholism; CYP2E1 gene; Papuan ethnicity; polymorphism

Abstrak: Penyalahgunaan alkohol dan intoksikasi alkohol dikaitkan dengan faktor genetik dan dipengaruhi oleh ras serta etnik tertentu. Gen penghasil enzim yang memetabolisme alkohol yaitu CYP2E1 bekerja pada retikulum endoplasma. Penelitian ini melihat polimorfisme gen CYP2E1 *5B dan CYP2E1 *6 dan hubungannya dengan perilaku minum alkohol pada etnis Papua di Yogyakarta. Terdapat 39 responden etnis Papua yang memenuhi kriteria. Hasil penelitian menunjukkan peminum alkohol sebanyak 29 orang (74,4\%) dan 10 orang (25,6\%) bukan peminum. Peminum berusia remaja akhir (89,7\%) dan berjenis kelamin pria (69,2\%). Genotip CYP2E1*5B yaitu c1/c1 sebanyak 94,9\%, c1/c2 sebanyak 5,1\%, dan tidak ditemukan genotip c2/c2. Genotip CYP2E1*6 yaitu genotip $\mathrm{T} / \mathrm{T}$ sebanyak 56,4\%, genotip $\mathrm{T} / \mathrm{A}$ sebanyak 43,6\%, dan tidak ditemukan genotip A/A. Odd ratio pada CYP2E1 *5B adalah 18,5 dan 7,7 pada CYP2E1 *6. Nilai p>0,05 pada gen CYP2E1 *5B dan CYP2E1 *6 terkait perilaku minum alkohol berupa frekuensi, durasi, jenis, dan volume alkohol yang dikonsumsi. Terdapat polimorfisme genotip c1/c1 dan c1/c2 pada CYP2E1 *5B serta genotip T/T dan T/A pada CYP2E1 *6 etnis Papua di Yogyakarta. Genotip c1/c1 memiliki kemungkinan 18,5 kali menjadi peminum alkohol dan genotip T/T memiliki kemungkinan 7,7 kali menjadi peminum alkohol pada etnis Papua. Jenis genotip tersebut secara statistik tidak berhubungan signifikan dengan perilaku minum alkohol pada etnis Papua

Kata Kunci: alkoholisme; gen CYP2E1; etnis Papua; polimorfisme 


\section{INTRODUCTION}

Alcohol is one of the active substances often misused in the community and causes dependence and poisoning. The risk of interference due to alcohol use increases even though many heavy drinkers excluded the criteria for alcohol dependence. In developing countries, alcoholism is one of the severe drug abuse problems. ${ }^{1}$ Alcohol causes death in adults, especially men, with a mortality rate of up to $25 \%$, depending on the type of alcohol. In addition, alcohol also plays a significant role around $7.4 \%$ by causing disability and premature death in the European Union. ${ }^{2,3,4}$

Several factors that affect alcohol consumption include psychosocial, environmental, genetic, and neurobiological conditions. Alcohol consumption in the long term will continuously damage the body's system. Brain and nervous system functions will be permanently damaged, resulting in hepatitis, cirrhosis, liver cancer, heart disease, high blood pressure, heart failure, stroke, and gastritis. ${ }^{5}$

Statistics show that there is a clear relationship between people who drink alcohol and criminal acts. The incidence of crime caused by alcohol is $24 \%-85 \% .{ }^{1}$ Although there are reported links between alcohol and criminal acts, the direct cause of these two conditions is still debatable. However, alcohol in clinical forensic medicine is still considered to have a relationship with criminal activity. The presence of alcohol in someone's body also has a vital role in physical assessment for detention. Understanding metabolism, effects, and problems caused by alcohol consumption is significant for a doctor, especially those involved in clinical forensic medicine. ${ }^{6}$

The population of Asian people, including Indonesian, has a deficiency of isozymes of ADH, CYP2E1, and ALDH; thus, acetaldehyde metabolism runs slowly in these individuals. Acetaldehyde can be built up due to drunk symptoms such as redness, tachycardia, hypotension, headache, nausea, vomiting, muscle weakness, and drowsiness, although the blood alcohol level is still relatively low. This situation has resulted in the Asian people's sensitivity to alcohol being very heterogeneous. ${ }^{7}$

In Indonesia, some regions have a high culture of drinking alcohol, such as Papua. There has been no report on CYP2E1 gene polymorphism on alcohol drinking behavior, especially on Papuans ethnic in Indonesia. Based on this reason, it is necessary to analyze CYP2E1 gene polymorphism towards people's drinking habits in Indonesia, especially in the Papuans ethnic. In various races and other ethnicities, there have been studies on the effect of the CYP2E1 polymorphism.

In relation to the aspect above, this research aims to determine the sensitivity to alcohol in several ethnic groups in Indonesia. Specifically, this research concerns genetic polymorphism for the enzymes that play a role in alcohol metabolism, namely the CYP2E1 enzyme. It analyzed CYP2E1 gene polymorphism in Papuans ethnic and the relationship with alcohol sensitivity. The results in this study were compared with studies from other populations to see if the polymorphisms in the Papuan population are similar to the Caucasian population and significantly different from the populations in East Asian countries, for example, China, Taiwan, and Japan.

\section{MATERIALS AND METHOD}

This study used a descriptive-analytical method by analyzing CYP2E1 gene polymorphism in Papuans ethnic. The population in this study was Papuan ethnic individuals who lived in the Special Region of Yogyakarta, willing to be examined and included in the inclusion and exclusion criteria. Samples were taken based on the consecutive sampling method. Inclusion criteria included male and female volunteers, Papuans ethnic, healthy, over 18 years of age, and signed informed consent. Meanwhile, the exclusion criteria were subjects related by blood and canceled their participation in the study for various reasons.

Peripheral blood sampling was carried out on 39 tested people (sample) that fulfilled the inclusion and exclusion criteria and collected in April 2018 at the Forensic Department Faculty of Medicine Gadjah Mada University. Each sample was taken for blood to examine the CYP2E1 gene polymorphism once. During the procedure, 1cc of venous blood sampling was carried out. Prior to taking blood, all the tested people were explained about the research, and informed consent was given to them. Furthermore, this study did not have any medical effects on the patient's condition, and the data collection process was carried anonymously. This study received an Ethical Clearance from the Ethics Commission of the Faculty of Medicine, Gadjah Mada University, Yogyakarta, with the number Ref: KE / FK / 0212 / EC / 2018.

Examination of polymorphism began with extravasation of DNA, measurement of DNA purity by a spectrometer, amplification, restriction fragment length polymorphisms (RFLP), electrophoresis, and finally, the reading process of the results. Data were analyzed by descriptive statistics and continued with analytic statistics by comparing the types of gene and allele polymorphisms with existing variables. The hypothesis 


\section{mutiara medika}

was tested in a $2 \times 2$ table and used the Chi-square test. Both tests were carried out with SPSS software. The average drinking volume, duration of drinking, and frequency of drinking in each CYP2E1 gene group were analyzed using ANOVA.

\section{RESULTS}

Out of 39 samples, only polymorphism was examined in this study on $\mathrm{CYP}_{2} \mathrm{E}_{1} *{ }_{5} \mathrm{~B}$ and $\mathrm{CYP} 2 \mathrm{E} 1 * 6$. Genetic polymorphism of the CYP2E1 gene was determined using polymerase chain reaction (PCR / RFLP). CYP2E1 gene fragment was amplified with PCR by forwarding primer pair 5'-TTCATTCTGTCTTCTAACTGG-3 'and reverse primer 5'-CCAGTCGAGTCTACATTGTCA-3' for Pst I and forwarding primer pair 5'AGTCGACATGTGATGGATCCA-3 'and then reversing primer 5'-GACAGGGTTTCATGTTGG-3' for Dral. PCR was conditioned for pre-denatured DNA in a program consisting of 30 s denaturations at 950C, 30 s annealing at 540 C for Pst I and $630 \mathrm{C}$ for Dra I, and 45s extensions at 720C. The PCR results were later electrophoresis with $2 \%$ agarose media, and the results can be seen in Figure 1.

Based on the results above, the distribution of DNA images in Papuan ethnic samples was around the range of $375 \mathrm{bp}$ and $400 \mathrm{bp}$. The CYP2E1 isozyme image or band was seen using UV light. In the following procedure, RFLP was visualized on $2.0 \%$ agarose gel for $\mathrm{CYP}_{2} \mathrm{E}_{1} * 5 \mathrm{~B}$ gene and in $1.5 \%$ gel for $\mathrm{CYP}_{2} \mathrm{E}_{1} * 6$ gene. $\mathrm{CYP} 2 \mathrm{E}_{1}$ *5B genotype was carried out by digesting 10 microunit PCR products separately with $10 \mathrm{U}$ Pst at $37^{\circ} \mathrm{C}$ for 18 hours and visualized on a $2.5 \%$ agarose gel. The $\mathrm{CYP}_{2} \mathrm{E}_{1} * 6$ genotype was determined by digesting 20 micro PCR product units with $6 \mathrm{U}$ Dral at $37^{\circ} \mathrm{C}$ for 24 hours. Furthermore, dral digestive results were analyzed respectively at $1.8 \%$ agarose gel. ${ }^{8}$

In this study, CYP2E1 polymorphisms; ${ }_{5} \mathrm{~B}$ located in 59-Xanking and *6 areas in Intron 6 had been observed in 39 Papuans ethnic samples living in Yogyakarta. CYP2E1*5B (C-1053T) polymorphisms digested with Pstl produced wild type genotypes * $1 \mathrm{~A} / * 1 \mathrm{~A}(\mathrm{c} 1 / \mathrm{c} 1),{ }_{1} \mathrm{~A} / * 5 \mathrm{~B}(\mathrm{c} 1 / \mathrm{C2})$ heterozygous, and * $5 \mathrm{~B} /{ }^{*} \mathrm{~B}$ $(C 2 / C 2)$ homozygote (variant). In figure 2 , you will see the results of $C Y P 2 E_{1}{ }^{*} 5 B$ electrophoresis after RFLP.

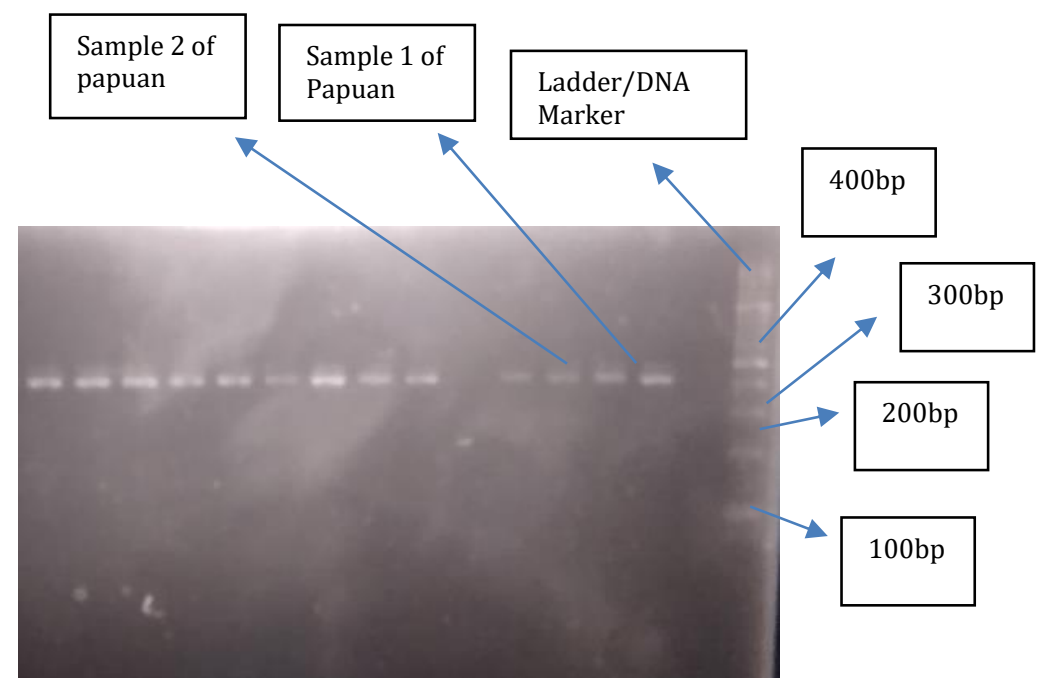

Figure 1. The use of PCR to all of the 39 samples and the PCR Results of Electrophoresis CYP2E1 Gene. CYP2E1 isozyme bands are visible under UV light due to ethidium bromide staining 


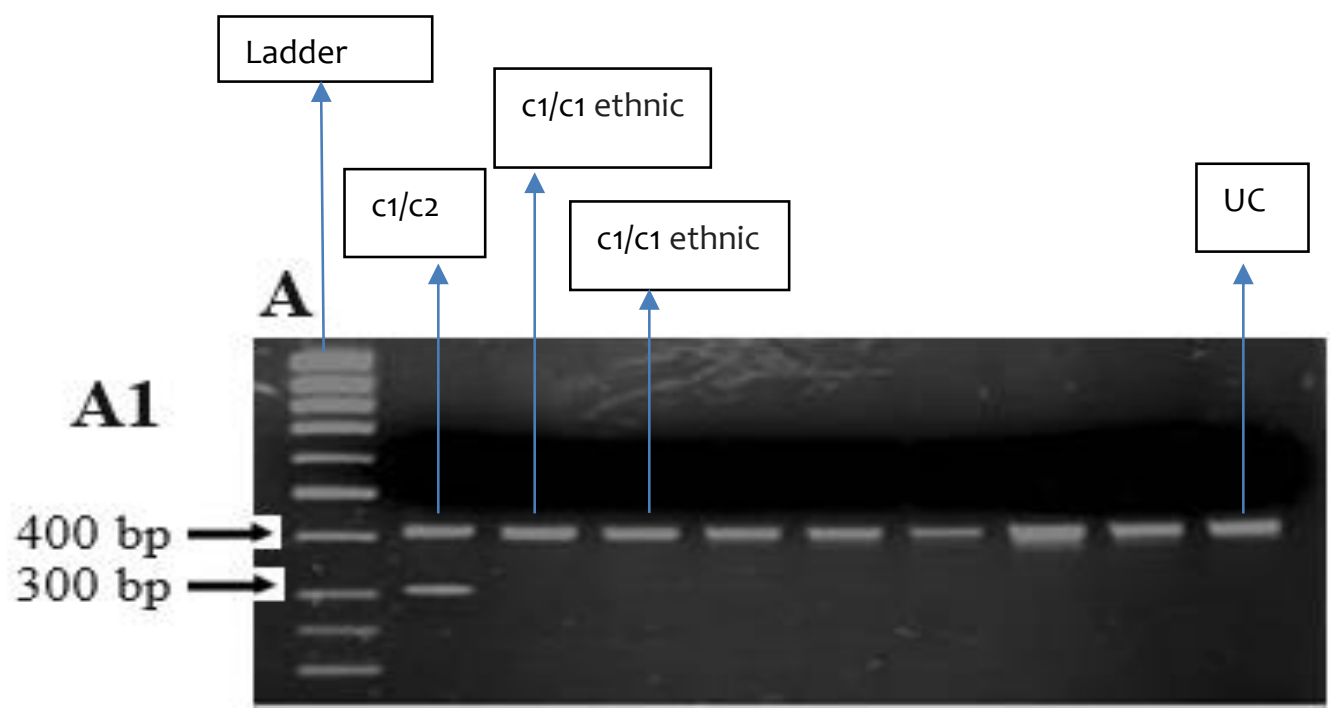

Figure 2. Result of RFLP Pst I. CYP2E1 polymorphism digested with Pstl.

In the CYP2E1*6 (T7632A) polymorphism, the digestion of PCR products with Dral produced a wild type $* 1 A / * 1 A(T / T)$ genotype, heterozygous *1A/*6 $(T / 3 q A)$ genotype and homozygous mutated variant * $6 / * 6$ $(\mathrm{A} / \mathrm{A})$ genotype as shown in Figure 3 .

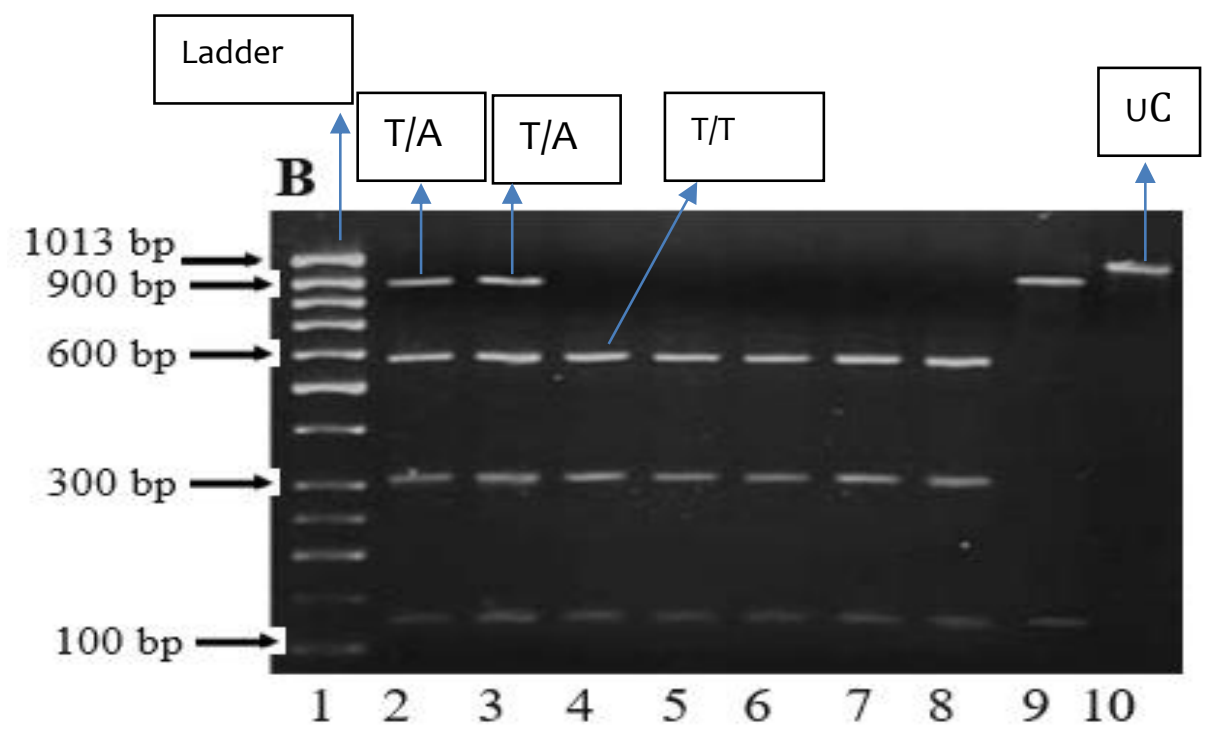

Figure 3. Result of RFLP Dra I. CYP2E1 polymorphism digested with Dral

The results of $\mathrm{CYP}_{2} \mathrm{E}_{1}{ }_{5} \mathrm{~B}(\mathrm{C}-1053 \mathrm{~T})$ polymorphisms were wild type homozygous if there was no site (410bp) with *1A $/ *_{1} A(c 1 / c 1)$ genotype. The result of $* 1 A / * 5 B(c 1 / c 2)$ was heterozygote if there was a site (29obp / 120bp / 410bp). The result of *5B/*5B (c2/ c2) was homozygous (variant) if there was a site (290bp / 120bp). Out of the 39 samples in this study, it was found that $\mathrm{c1}$ / c1 genotypes were $94.9 \%, \mathrm{c} 1$ / c2 genotypes were $5.1 \%$, and $\mathrm{C}_{2} / \mathrm{C} 2$ genotypes were not found.

The results of $\mathrm{CYP}_{2} \mathrm{E}_{1} * 6(\mathrm{~T} 7632 \mathrm{~A})$ polymorphism were wild-type homozygous if there was no site (375bp) with $*_{1} \mathrm{~A} / *_{1} \mathrm{~A}(\mathrm{~T} / \mathrm{T})$ genotype. The result of $*_{1} \mathrm{~A} / *_{6}(\mathrm{~T} / \mathrm{A})$ was heterozygote if there was a site (249bp/126bp/375bp). The result of *6/*6 (A/A) was homozygote (variant) if there was a site (249bp/126bp). Out of the 39 samples in this study, T/T genotyping frequency was obtained of $56.4 \%, T / A$ genotype of $43.6 \%$, while A/A genotypes were not found.

The results then performed allele frequency calculations carried out by the Hardy-Weinberg equilibrium formula $(p 2+2 p q+q 2)$. The calculation results showed that the possibility of the emergence of the $\mathrm{C} 1 / \mathrm{c} 1$ and $\mathrm{T} / \mathrm{A}$ genes was higher than the other genes.

Moreover, the sample was also divided into categories of alcoholic drinkers and non-alcoholic drinkers. The researchers then identified the difference based on the frequency of drinking alcohol, the 
duration of drinking alcohol, and the volume of alcohol consumed. It is more clearly stated in Table 1 for CYP2E1*5B and CYP2E1 * 6 was seen in Table 2.

Table 1. Polymorphism of CYP2E1*5B on Drinkers and Non-drinkers of Alcohol

\begin{tabular}{|c|c|c|c|c|c|c|c|}
\hline \multirow{2}{*}{ Variable } & & \multirow[b]{2}{*}{ n (\%) } & $\begin{array}{c}\text { CYP2E1 } \\
\mathrm{c} 1 / \mathrm{c} 1\end{array}$ & $\begin{array}{c}\text { CYP2E1 } \\
\mathrm{c} 1 / \mathrm{c} 2\end{array}$ & $\begin{array}{c}\text { CYP2E1 } \\
\text { c2/c2 }\end{array}$ & \multirow[t]{2}{*}{$\mathrm{P}$} & \multirow[t]{2}{*}{ OR } \\
\hline & & & n (\%) & n (\%) & n (\%) & & \\
\hline \multirow{4}{*}{$\begin{array}{l}\text { Alcohol } \\
\text { drinker }\end{array}$} & & 29 & 27 & 2 & - & 0.548 & 18.5 \\
\hline & Yes & $(74.3)$ & $(69.2)$ & (5.1) & & & \\
\hline & & 10 & 10 & 0 & - & & \\
\hline & No & (25.7) & $(25.7)$ & (0) & & & \\
\hline
\end{tabular}

Table 2. Polymorphism of CYP2E1*6 on Drinkers and Non-drinkers of Alcohol

\begin{tabular}{cccccccc}
\hline Variable & & $\mathrm{n}(\%)$ & $\begin{array}{c}\text { CYP2E1 T/T } \\
\mathrm{n}(\%)\end{array}$ & $\begin{array}{c}\text { CYP2E1 } \\
\mathrm{T} / \mathrm{A}(\%)\end{array}$ & $\begin{array}{c}\text { CYP2E1 T/T } \\
\mathrm{n}(\%)\end{array}$ & $\mathrm{P}$ & OR \\
\hline $\begin{array}{c}\text { Alcohol } \\
\text { drinker }\end{array}$ & Yes & $29(74.3)$ & $13(38.4)$ & $16(28.2)$ & - & \multirow{2}{*}{0.544} & 7.7 \\
\hline
\end{tabular}

This study also observed the relationship between alcohol drinking behavior in the form of frequency, volume, and duration of drinking alcohol in each type of CYP2 $\mathrm{E}_{1} * 5 \mathrm{~B}$ and $\mathrm{CYP}_{2} \mathrm{E}_{1} * 6$ genes. The results can be seen in Table 3 .

Table 3. Drinking Behavior Categories Based on Frequency, Volume, and Duration in the CYP2E1 Gene

\begin{tabular}{ccccccc}
\hline & $\begin{array}{c}\mathrm{c} 1 / \mathrm{c} 1 \\
(\mathrm{n}=27)\end{array}$ & $\begin{array}{c}\mathrm{c} 1 / \mathrm{c} 2 \\
(\mathrm{n}=2)\end{array}$ & $\mathrm{p}$ & $\begin{array}{c}\mathrm{T} / \mathrm{T} \\
(\mathrm{n}=13)\end{array}$ & $\begin{array}{c}\mathrm{T} / \mathrm{A} \\
(\mathrm{n}=16)\end{array}$ & $\mathrm{p}$ \\
\hline $\begin{array}{c}\text { Average drinking } \\
\text { volume per month }\end{array}$ & 2.35 & 2.50 & 0.780 & 2.42 & 2.31 & 0.717 \\
$\begin{array}{c}\text { Average drinking } \\
\text { frequency per month }\end{array}$ & 1.81 & 2.00 & 0.741 & 2.00 & 1.69 & 0.298 \\
$\begin{array}{c}\text { Average drinking } \\
\text { duration per year }\end{array}$ & 2.62 & 3.00 & 0.358 & 2.67 & 2.63 & 0.849 \\
\hline
\end{tabular}

Based on the results of data analysis on $\mathrm{CYP}_{2} \mathrm{E}_{1} * 5 \mathrm{~B}$ and $\mathrm{CYP}_{2} \mathrm{E}_{1} * 6$, it showed that there was no statistically significant difference in frequency, duration, and volume as they had a significance value greater than 0.05 (Table 3). It indicated that those who consumed a lot or consumed less alcohol did not affect the polymorphism of $\mathrm{CYP}_{2} \mathrm{E}_{1} * 5 \mathrm{~B}$ and $\mathrm{CYP}_{2} \mathrm{E}_{1} * 6$ genes.

\section{DISCUSSION}

CYP2E1 has a particular spectrum of substrates and has inducibility by toxic and carcinogenic compounds. The CYP2E1 gene has several polymorphisms linked to ethanol metabolism and increased genetic susceptibility to certain types of diseases caused by chemicals, including several types of cancer. 9,10

The frequency of CYP2E1 polymorphisms showed variability in different races and ethnicities, similar to most other xenobiotic metabolic enzymes. The results obtained in this study are compared with studies from other populations showing that the Papuan population is similar to the Caucasian population and significantly different from the population in East Asian countries, namely China, Taiwan, and Japan. Whereas, for the $\mathrm{CYP}_{2} \mathrm{E}_{1} * 6$, it was found for the Papuan population significantly different from the Caucasian population and significantly similar to Asia. ${ }^{11}$

After the RFLP, the expected results in this study were the distribution of these three CYP2E1 genotypes to Papuans ethnic. Papuans Ethnic are part of the Austromelanosoid race. The distribution of the CYP2E1 genotype has not been well documented as there has been little research on CYP2E1 in metabolizing alcohol. Likewise, the CYP2E1 study on other ethnic groups still included in the Austromelanosoid race has 
never been done, for example, in Papua New Guinea ethnic, so the comparison is difficult. Several studies stated that the $\mathrm{CYP}_{2} \mathrm{E}_{1}{ }_{5} 5 \mathrm{~B}$ gene influenced most alcohol metabolism in the endoplasmic reticulum, while the CYP2E1*6 more affected cancer incidence. ${ }^{12}$

The P-value of the CYP2E1 genotypes is more significant than 0.05; thus, it can be concluded that the relationship between $\mathrm{CYP}_{2} \mathrm{E}_{1} * 5 \mathrm{~B}$ and $\mathrm{CYP}_{2} \mathrm{E}_{1} * 6$ gene polymorphisms and between alcohol drinkers and nonalcoholic drinkers did not differ statistically. Furthermore, several studies from other populations also showed similar results, for example, in Taiwan's Han population. The type of gene presented in CYP2E1 was considered affecting ethanol metabolism in the endoplasmic reticulum, which could change to acetaldehyde or reverse quickly. It resulted in a person with a certain type of gene not immediately feeling the effects of alcohol after drinking it and provide a protective effect on alcohol.

The protective effect is the tendency not to drink alcohol and be susceptible to toxic effects that can damage various organs in the body, causing diseases such as cirrhosis of the liver and others. ${ }^{11}$ This protective effect can make someone stay away or refrain from drinking more alcohol to prevent them from becoming alcoholics. Individuals with this gene can reduce their risk of becoming alcoholics up to 10 times. ${ }^{12}$

Ethanol metabolism into acetaldehyde is influenced by two enzymes, namely ADH and CYP2E1; in the literature, $A D H$ plays a more significant role of around $90 \%$ compared to CYP2E1 that was only the remaining $10 \%$. Metabolism by CYP2E1 is also preferred in chronic alcohol drinkers. These reasons are believed to be one of the reasons why, in many studies, there is no correlation between CYP2E1 polymorphism and the habit of drinking alcohol.

In this study, there were also different odds ratios for $\mathrm{CYP}_{2} \mathrm{E}_{1} * 5 \mathrm{~B}$ and $\mathrm{CYP}_{2} \mathrm{E}_{1} * 6$. Based on the odds ratio, it can be concluded that Papuans ethnic with $\mathrm{c} 1 / \mathrm{c} 1$ alleles is 18.5 times more likely to be alcoholic drinkers, while Papuans ethnic with $\mathrm{T} / \mathrm{T}$ alleles are 7.7 times more likely to be alcoholic drinkers. In other words, Papuans ethnic who have $\mathrm{c} 1 / \mathrm{c} 2$ and $\mathrm{T} A$ alleles have protective effects in their bodies against alcohol. Thus, they will tend to avoid consuming alcohol.

The result above indicates that those who consume a lot or consume less alcohol do not affect the polymorphism of $\mathrm{CYP}_{2} \mathrm{E}_{1} * 5 \mathrm{~B}$ and $\mathrm{CYP}_{2} \mathrm{E}_{1} * 6$ genes. Similar results were obtained in many other studies such as in the Han population in Taiwan, the Caucasian population, and various other populations. ${ }^{13}$

The relationship of CYP2E1 gene polymorphism between alcoholic drinkers and non-alcoholic drinkers does not show a relationship related to Papuan in this study. Some literature states that the type of alelc1/c1 is wildly homozygous, an extensive metabolizer. Thus, individuals with a wild homozygous allele (extensive metabolizer) will consume more alcohol per day than the heterozygous deletion (poor metabolizer). It happens because, in that allele, the ethanol will change to become longer acetaldehyde. In contrast, the ethanol in alcohol drinkers with poor metabolizers, especially new addicts, can reduce a person's risk of alcohol addiction. After all, acetaldehyde develops faster, and a more extended shelf of alcohol can cause many side effects of alcohol intoxication. ${ }^{14}$

In this case, the protective effect mainly occurred in individuals with the $\mathrm{c} 2 / \mathrm{c}_{2}$ homozygous gene. In individuals with this gene, alcohol consumption could have unpleasant effects such as cardiovascular effects, dysphoria, palpitations, dry mouth, headaches, nausea, and facial warning, which arose due to the accumulation of acetaldehyde in the blood. ${ }^{15}$

These unpleasant effects caused individuals with the $\mathrm{c2}_{2} / \mathrm{c} 2$ gene to stay away or hold them to drink more amounts of alcohol, preventing them from becoming alcoholics. Based on the results of several studies on CYP2E1, it was revealed that CYP2E1*6 was not very significant in the alcohol metabolism process. CYP2E1 in the endoplasmic reticulum contributed only $10 \%$ in the overall process of ethanol metabolism to acetaldehyde. Some of these reasons lead to many things that can affect a person's metabolism after consuming alcohol, and it also determines whether a person becomes alcoholic or not.

\section{CONCLUSION}

Based on the result of this study, it can be concluded that there was no difference in the proportion between CYP2E1 types and alcohol drinking habits in Papuan ethnicity. The drinking patterns based on frequency, duration, or volume of alcohol consumed also did not differ with the type of CYP2E1 gene polymorphism. Furthermore, genotype $\mathrm{c} 1 / \mathrm{c} 1$ was 18.5 times more likely to be alcoholic drinkers, and T T genotypes were 7.7 times more likely to be alcoholic drinkers in Papuan ethnicity. 


\section{mutiara \\ medika}

\section{ACKNOWLEDGEMENT}

The authors' gratitude goes to the Faculty of Medicine Gadjah Mada University, Faculty of Medicine and Health Sciences Universitas Muhammadiyah Yogyakarta and volunteers who were willing to participate in this research.

\section{CONFLICT OF INTEREST}

The authors declare there is no potential conflict of interest.

\section{REFERENCES}

1. Connor JP, Haber PS, \& Hall WD. Alcohol use Disorders. The Lancet. 2016. 387(10022): 988-998.

2. WHO. Estimated Cancer Incidence, Mortality and Prevalence Worldwide in 2002.2002 ; http://globocan.iarc.fr/Pages/fact_sheets_population.aspx

3. Anderson P, Baumberg B. Alcohol in Europe: A Public Health Perspective. Health and Consumer Protection. Directorate General Europe Commision. 2006; 24-5.

4. Arias A, Andreu A, Rodriguez C, Sierra A, Arevalo MP. Determination of the Beta-Blocker Atenolol in Plasma by Capillary Electrophoresis. Journal of Chromatography. 2009; 916 (1-2): 297-304.

5. Lowinson JH, Ruiz R, Millman RB, Langord JG. Substance Abuse: A Comprehensive Textbook. Fourth Edition. Lippincott: Williams \& Wilkins. 2006; 512: 1-2.

6. Stark MM, Norfolk G. Clinical Forensic Medicine A Physician's Guide in $2^{\text {nd }}$ ed., Humana Press. New Jersey. 2005; 305-316.

7. Budiyanto A, Widiatmaka W, Sudiono S, Winardi T, Idries AM, Sidhi. Ilmu Kedokteran Forensik. Edisi Pertama, Cetakan Kedua. Jakarta: Fakultas Kedokteran Universitas Indonesia. 2007.

8. Gunn ZA. Alcohol and CYP2E1 Genotypes and Alcoholism in Chinese Men. Am. J. Hum. Genet. 2009; 48. 677-681.

9. Djordjevic N, Carrillo JN, Broek MPJVD, Kishikawa J, Roh HK, Bertilsson L, Aklillu E. Comparisons of CYP2E1 Genotype and Enzyme Activity between Swedens and Koreans. Drug Metab Pharmacokinet. 2013; 28 (2): 93-97.

10. Zanger UM, and Kathrin K. Pharmacogenetics of Cytochrome P450: Advances on Polymorphisms, Mechanisms, and Clinical Relevance. Frontiers in Genetics. 2013; 4: 24. https://doi.org/10.3389/fgene.2013.00024

11. Prahlow J. Drug Related and Toxin Related Death in Forensic Pathology for Police, Death Investigators, Attorneys and Forensic Scientist. Humana Press. New Jersey. 2010; 269-272.

12. Quertemont E. Genetic Polymorphism in Ethanol Metabolism: Acetaldehyde Contribution to Alcohol Abuse and Alcoholism. Molecular Psychiatry. 2004; 9(6): 570-581. https://doi.org/10.1038/sj.mp.4001497

13. Rajendram R, Hunter R, Preedy V. Alcohol, Encyclopedia of Human Nutrition. 2005; vol. 2: 4857.

14. Luczek CH, Celinski K, Wojcierowski J, Slomka M, Lis E. Genetic Polymorphism of Alcohol Metabolizing Enzime. Brazillian Journal of Medical and Biological Research. 2004: 43. 257-261. https://doi.org/10.1590/S0100. $\underline{879 \times 2010007500006}$

15. Plemenitas A, Kastelic M, Porcelli S, Serretti A, Rus Makovec M, Kores Plesnicar B. Genetic Variability In CYP2E1 and Catalase Gene among Currently and Formerly Alcohol-Dependent Male Subjects. Alcohol and Alcoholism. 2015; 50(2): 140-145. https://doi.org/10.1093/alcalc/agu088 